\title{
Basic and clinical immunology - 3022. Inhibitory action of fexofenadine hydrochloride on mast cell activation in vitro
}

\author{
Miyuki Suzuki ${ }^{1 *}$, Atsuko Furuta ${ }^{1}$, Kazuhito Asano², Harumi Suzaki \\ From 2nd WAO International Scientific Conference (WISC 2012) \\ Hyderabad, India. 6-9 December 2012
}

\section{Background}

Allergic rhinitis is well known to be accompanied by inflammatory responses in the nasal wall and lumen including predominant infiltration of eosinophils, $\mathrm{T}$ cells and mast cells. With the discovery of IgE as the link between allergen exposure and mediator release, mast cells established their role as effector cells in the development and maintenance of allergic diseases. However, the influence of histamine $\mathrm{H}_{1}$-receptor antagonists on mast cells activation is not fully understood. The present study, therefore, was undertaken to examine the influence of histamine $\mathrm{H}_{1}$-receptor antagonist on mast cells activation by using an in vitro cell culture technique and fexofenadine hydrochloride (FEX).

\section{Methods}

Spleen cells obtained from BALB/c mice were cultured for 3 weeks in the presence of FEX, and the number of mast cells was counted with alcian blue. We also examined the influence of FEX on mast cells activation. Cultured mast cells were sensitized with OVA-specific IgE and these sensitized cells were stimulated with OVA in the presence of FEX for 4 hours. The levels of tumor necrosis factor (TNF)- $\alpha$, vascular endothelial growth factor (VEGF) and keratinocyte-derived chemokine $(\mathrm{KC})$ were examined by ELISA.

\section{Results}

FEX could not suppress mast cell growth from progenitor cells in spleen cell suspension, even when $500 \mathrm{ng} / \mathrm{ml}$ of the agent was added to cell cultures. On the other hand, treatment of mast cells with FEX caused suppression of

'Department of Otorhinolaryngology, School of Medicine, Showa University, Tokyo, Japan

Full list of author information is available at the end of the article factor production from mast cells by antigenic stimulation. The minimum concentration of the agent that caused significant suppression was $200 \mathrm{ng} / \mathrm{ml}$.

\section{Conclusions}

The present results strongly suggest that FEX exerts inhibitory effects on mast activation and results in favorable modification of clinical status of pollinosis patients.

\section{Author details}

'Department of Otorhinolaryngology, School of Medicine, Showa University, Tokyo, Japan. ${ }^{2}$ Physiology, Showa University, Japan.

Published: 23 April 2013

\section{doi:10.1186/1939-4551-6-S1-P198}

Cite this article as: Suzuki et al:: Basic and clinical immunology - 3022

Inhibitory action of fexofenadine hydrochloride on mast cell activation in vitro. World Allergy Organization Journal 2013 6(Suppl 1):P198.

Submit your next manuscript to BioMed Central and take full advantage of:

- Convenient online submission

- Thorough peer review

- No space constraints or color figure charges

- Immediate publication on acceptance

- Inclusion in PubMed, CAS, Scopus and Google Scholar

- Research which is freely available for redistribution

\section{Biomed Central}

(c) 2013 Suzuki et al; licensee BioMed Central Ltd. This is an Open Access article distributed under the terms of the Creative Commons Attribution License (http://creativecommons.org/licenses/by/2.0), which permits unrestricted use, distribution, and reproduction in any medium, provided the original work is properly cited. 